\title{
EVALUASI PROGRAM KONSERVASI CAGAR BUDAYA MELALUI MEKANISME PEMBERIAN SUBSIDI DI KAWASAN KOTA LAMA SAWAHLUNTO
}

\section{EVALUATION OF CULTURAL HERITAGE CONSERVATION PROGRAMS WITH A SUBSIDIZINC MECHANISM IN THE OLD TOWN SAWAHLUNTO.}

\section{Budi Kurniawan}

Magister Perencanaan Wilayah dan Kota, Universitas Gadjah Mada Yogyakarta;

bk.arch99@yahoo.com

Info Artikel:

- Artikel Masuk: 21 Oktober 2019

\begin{abstract}
ABSTRAK
Program konservasi cagar budaya melalui mekanisme pemberian insentif (subsidi) telah dilakukan pada permukiman eks buruh tambang batubara di Kawasan Kota Lama Sawahlunto (2007 - 2012). Pendekatan evaluasi-studi kasus (kualitatif) dilakukan untuk menggambarkan tahapan program pemugaran fasad serta faktor-faktor yang mempengaruhinya, kemudian dilakukan penilaian terhadap kriteria relevansi, efektifitas, efisiensi, dan keberlanjutan. Berdasarkan evaluasi ditemukan adanya ketidaksesuaian (mismatch) antara kondisi yang direncanakan dengan kebutuhan warga penerima subsidi, serta ditemukan adanya unsur keterpaksaan dalam partisipasi. Selain itu juga ditemukan kelemahan dalam manajemen kegiatan dan terbatasnya sumberdaya yang tersedia. Sehingga dalam pelaksanaannya terjadi bentuk penyimpangan partisipasi yang disebabkan oleh rendahnya komitmen dan motivasi masyarakat. Melalui pemberian subsidi memang diperoleh efisiensi biaya yang tinggi, karena keseluruhan (100\%) dana subsidi yang diberikan terserap dengan baik dan bahkan masyarakat bersedia menggunakan dana pribadi mereka untuk menutupi kekurangan biaya pekerjaan. Namun, program tersebut menjadi kurang efektif dalam konteks pelestarian kawasan cagar budaya karena output yang dihasilkan memiliki kesesuaian yang rendah (18,4\%) dengan rencana. Dan pada pasca program, ditemukan kecenderungan kawasan untuk berubah kembali melalui berbagai pelanggaran dan penambahan ruang yang dilakukan oleh penerima subsidi. Sehingga pada akhirnya hasil (output-outcome) yang diharapkan belum tercapai sepenuhnya, dan program tidak berlanjut sebagaimana diharapkan.
\end{abstract}

Kata Kunci : Evaluasi; Konservasi Cagar Budaya; Subsidi;Partisipasi

\section{ABSTRACT}

The heritage conservation program through the mechanism of providing incentives (subsidies) has been carried out in coal mining worker settlements in the Old Town of Sawahlunto (2007 - 2012). An evaluation - case study approach (qualitative) was carried out to describe the stages of the facade restoration program and the affecting factors, then an evaluation of the criteria of relevance, effectiveness, efficiency and sustainability was carried out. Based on the evaluation it was found that there was a mismatch between the planned conditions and the needs of the community, and it was found that there was an element of coercion in community participation. It also found weaknesses in activity management and the limited available resources. As a result, there has been a deviation in participation due to the low level of community commitment. Through the provision of subsidies, high cost efficiencies have been obtained, because overall (100\%) of the subsidized funds provided are well absorbed and even the community is willing to use their private funds to cover the lack of work costs. However, the program has become less effective in the context of preservation of cultural heritage areas because the resulting output has low conformity with the plan. And in the aftermath of the program, it was found that the region's tendency to change again through various violations and the addition of space committed by recipients of subsidies. So in the end the expected outputs have not yet been achieved, and the program does not continue as expected.

Keyword: Evaluation; Heritage Conservation;Subsidy; Participation 


\section{PENDAHULUAN}

Rangkaian kegiatan Revitalisasi dan Konservasi di Kawasan Kota Lama Sawahlunto (2001-2012) dilatar belakangi oleh krisis pasca tambang dan visi Pemerintah untuk bertransformasi menjadi kota wisata tambang yang berbudaya. Revitalisasi dan konservasi dilakukan dengan memanfaatkan "sisa" peninggalan kegiatan pertambangan dan menjadikannya sebagai aset penting dalam pengembangan pariwisata.

Salah satu bagian dari rangkaian kegiatan tersebut adalah konservasi permukiman buruh tambang pada kawasan kota lama. Radzuan et al. (2014) dalam penelitiannya terhadap pemberian insentif dalam program konservasi, menyatakan bahwa proyek konservasi dengan pemberian insentif akan efektif jika ada keterkaitan kebijakan insentif dengan kebutuhan komunitas (masyarakat). Dan partisipasi masyarakat merupakan faktor utama yang menentukan keberhasilan dan efektifitas program.

Kemudian Febra (2016) dalam temuannya menyimpulkan bahwa masyarakat Kota Lama Sawahlunto memiliki tingkat partisipasi yang tinggi (29,2\%) dan sangat tinggi (33,8\%) dalam upaya pelestarian. Dan ada pengaruh signifikan faktor pengetahuan, usia, lama tinggal, jumlah keluarga, tingkat pendidikan dan sosialisasi program terhadap tingkat partisipasi masyarakat.

Namun berdasarkan dokumen kegiatan \& laporan, peneliti menemukan bahwa output yang dihasilkan program belum sesuai dengan apa yang direncanakan. Bahkan setelah 7 (tujuh) tahun sejak program telah selesai dilaksanakan (2012), ditemukan kecenderungan kawasan untuk berubah kembali pada kondisi pra program. Dimana mulai banyak bangunan yang telah dipugar, kembali melakukan perubahan fasad maupun penambahan ruang atau massa bangunan (infill).

Selain itu Radzuan et al. (2015) menemukan adanya ketidaksesuaian antara tujuan kebijakan insentif yang lebih sebagai katalis dalam pengembangan wisata budaya, ketimbang memenuhi apa yang dibutuhkan masyarakat. Radzuan dan Ahmad (2016) menegaskan kembali bahwa perumusan kebijakan insentif dalam konservasi cagar budaya harus mencerminkan kebutuhan nyata dari komunitas yang berpartisipasi. Sedangkan Cherish (2014)memandang bahwa sesuai amanat UU Cagar Budaya No. 11 Tahun 2010 dan visi Pemerintah untuk menjadikan Kota Sawahlunto sebagai Kota Wisata Tambang, kebijakan untuk melakukan konservasi di Kawasan Kota Lama sangat perlu dilakukan untuk memelihara nilai sejarah dan budaya serta pengembangan wisata budaya. Terlebih pada saat itu kawasan telah berkembang menjadi tidak teratur dan cenderung kumuh.

Penelitian ini adalah penelitian evaluasi - studi kasus (GAO, 1990; Yin, 2012) sehingga tujuan utama penelitian adalah melakukan evaluasi terhadap implementasi program pemugaran fasad melalui pemberian subsidi di permukiman eks buruh tambang Tanah Lapang di Kawasan Kota Lama Sawahlunto (How), dan mengidentifikasi faktor-faktor yang mempengaruhinya (Why). Kemudian baru dilakukan penilaian terhadap kriteria relevansi, efektifitas, efisiensi dan keberlanjutan.

\section{DATA DAN METODE}

\subsection{Pengumpulan Data}

Data mengenai partisipasi masyarakat pada keseluruhan rangkaian kegiatan (input-activity-outputoutcome) dikumpulkan melalui angket untuk mendapat gambaran menyeluruh terhadap pelaksanaan program. Angket diberikan kepada warga penerima subsidi dengan jumlah sampel $40 \mathrm{KK}$. Kemudian dilakukan wawancara mendalam secara purposive sampling, baik dengan masyarakat penerima subsidi maupun dengan pengelola kegiatan pada instansi pemerintah yang berwenang. Penilaian pada output program didasarkan pada berbagai dokumen kegiatan, laporan pengawas dan dokumentasi lainnya, sedangkan penilaian terhadap outcome program lebih didasarkan pada penilaian peneliti melalui observasi terhadap kondisi terkini di lapangan. Karena pada suatu penelitian kualitatif, peneliti bertindak sebagai instrumen utama. Analisa data dilakukan dengan triangulasi, baik menurut sumber atau metoda pengumpulan data. Dan adapun unit amatan pada penelitian ini adalah kawasan permukiman eks buruh tambang di Kelurahan Tanah Lapang yang berada di Kawasan Kota Lama Sawahlunto. 


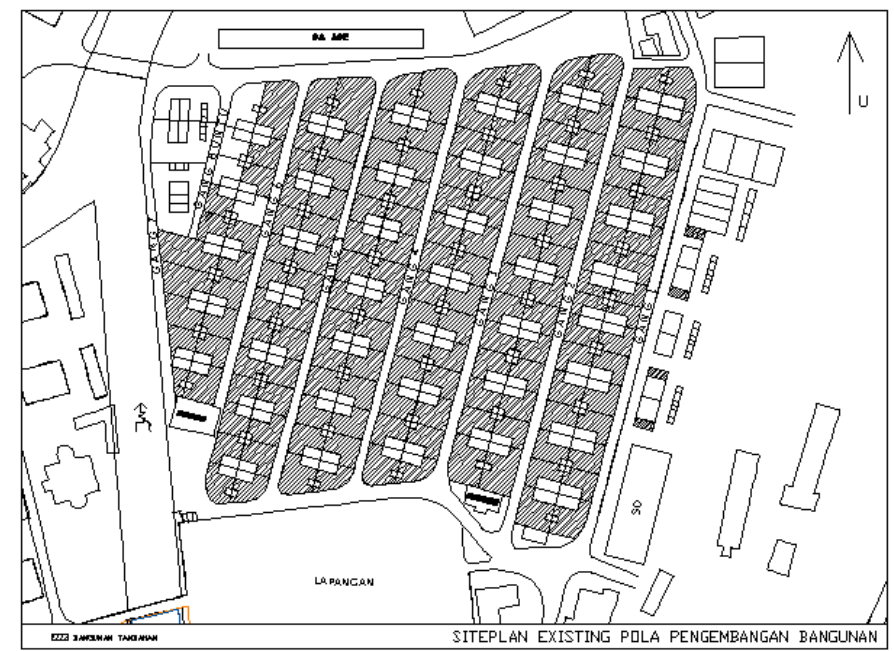

Sumber: BPKBP Sawahlunto, 2019

Gambar 1.Peta permukiman eks buruh tambang di Kawasan Kota Lama Sawahlunto

\subsection{Model Evaluasi}

Model evaluasi input-output (Pollitt dan Bouckaert, 2011) digunakan untuk menggambarkan tahapan program secara sistematis dan menyeluruh (Need-Objective-Input-Activity-Output-Outcome) beserta identifikasi faktor-faktor yang mempengaruhinya. Kemudian barulah dilakukan penilaian terhadap terhadap variabel relevansi, efektifitas, efisiensi dan keberlanjutan. Sedangkan faktor-faktor yang mempengaruhi program konservasi diidentifikasi dengan pendekatan deduktif kualitatif berdasarkan berbagai literatur tentang implementasi kebijakan dan program konservasi.

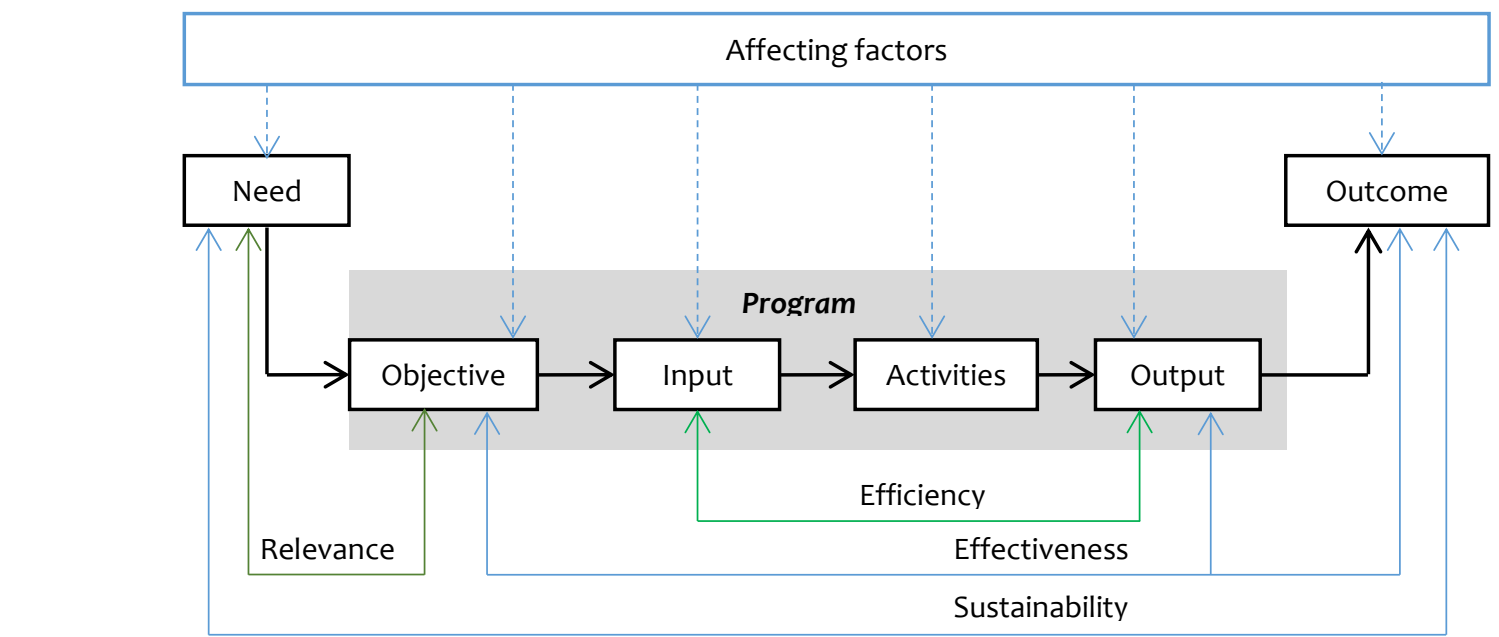

Sumber: adaptasi dari Pollit \& Bouckaert, 2011

Gambar2.Model evaluasi input-output

\section{HASIL DAN PEMBAHASAN}

3.1. Tahapan program (Need-Objective-Input-Activity-Output-Outcome).

3.1.1. Need/Problem.

Permasalahan yang melatar belakangi pelaksanaan pemugaran fasad di Permukiman Eks Buruh Tambang di Kelurahan Tanah Lapang adalah perubahan bentuk fisik permukiman buruh tambang Tanah 
Lapang, yang menjadi tidak teratur dan cenderung kumuh sehingga dikhawatirkan mengancam kelestarian nilai sejarah budaya yang melekat pada kawasan kota lama Sawahlunto (Cherish, 2014).

Sedangkan fenomena yang terjadi adalah permukiman tersebut telah berubah fungsinya, dari awalnya sebagai barak buruh tambang batubara, kemudian berkembang menjadi hunian keluarga untuk karyawan perusahaan tambang. Bahkan meskipun permukiman tersebut secara sah dimiliki oleh PTBA (BUMN), rumah-rumah tersebut banyak yang kemudian "dijual" oleh karyawan tambang kepada pihak lain (masyarakat umum). Hal tersebut terjadi karena perkembangan kebutuhan terhadap hunian tidak terakomodasi akibat terbatasnya ketersediaan lahan dan kondisi topografi kawasan yang berupa perbukitan. Hampir sebagian besar lahan di Kawasan Kota Lama merupakan asset perusahaan (PTBA, PT $\mathrm{KAl}$ ) yang diwariskan sejak penambangan pada zaman kolonial.

Akibatnya, permukiman eks buruh tambang batubara Tanah Lapang berkembang menjadi permukiman padat. Dan masyarakat melakukan adaptasi dengan menambah ruang dan menambah fungsi lainnya (carport, pagar, taman, jemuran, dIl). Perubahan bentuk fisik tersebutlah kemudian yang mendasari Pemerintah Daerah merasa perlu untuk melakukan intervensi melalui Program Pemugaran Fasad.

Sehingga faktor-faktor yang mempengaruhi kebutuhan masyarakat dan permasalahan adalah: perubahan fungsi bangunan(Hanafi et al., 2017),kepemilikan lahan(Hocking et al., 2008), kebutuhan hunian(Veillon, 2014), dan kondisi lingkungan (topografi) (Hocking et al, 2008).

\subsubsection{Objective.}

Berdasarkan dokumen kegiatan yang diperoleh, tujuan utama dari program pemugaran fasad pada permukiman eks buruh tambang Tanah Lapang adalah menyelamatkan dan merawat bangunan bersejarah yang ada. Selain itu perubahan yang dilakukan diharapkan akan memberi dampak ekonomi terhadap masyarakat melalui aktifitas pariwisata, serta melalui pemberian subsidi dapat mengurangi beban masyarakat secara ekonomi dalam hal perawatan bangunan.

Namun kebijakan tersebut dibuat dengan pendekatan top-down atau kurang melibatkan warga (komunitas) pada permukiman tersebut, padahal langkah awal yang krusial dalam implementasi konservasi adalah melibatkan masyarakat dalam perencanaan dan perumusan kebijakan (Villiers, 2009). Selain itu kebijakan dengan insentif merupakan kebijakan yang masih baru atau belum pernah sebelumnya dilakukan, ditambah kebijakan tersebut bersifat kontroversi karena ada potensi warga dirugikan akibat penambahan bangunan yang ada harus dibongkar. Kebijakan yang baru dan kontroversi cenderung akan menemui kendala pada pelaksanaannya dan kurang mendapat dukungan masyarakat (Winarno, 2014)

Sehingga faktor-faktor yang mempengaruhi tujuan program adalah: karakteristik kebijakan (Hamdi, 2015; Winarno, 2014) dan partisipasi masyarakat dalam perumusan kebijakan(Hamdi, 2015; Roy dan Kalindi, 2017; Villiers, 2009).

\subsubsection{Input.}

Input pada program pemugaran fasad adalah anggaran (finansial), sumberdaya manusia, dan kebijakan konservasi. Berdasarkan data yang diperoleh diketahui bahwa anggaran yang ada di Pemerintah cukup terbatas, namun masih mencukupi dan dapat dilakukan dengan beberapa tahap. Kemudian juga diketahui bahwa SDM pada bidang konservasi yang ada di Pemerintah juga terbatas (Nurcahyo, 2015), baik dari segi jumlah personil maupun pengetahuan dalam bidang konservasi. Akibat keterbatasan sumberdaya maka program pemugaran fasad dirancang dengan pendekatan swakelola. Studi, perencanaan dan pengawasan dilakukan secara swakelola oleh instansi pemerintah yang berwenang (Bidang Peninggalan Bersejarah dan Permuseuman pada Dinas Pariwisata dan Kebudayaan Kota Sawahlunto). Sedangkan pelaksanaan fisik pemugaran diserahkan pada warga penerima subsidi.

Sehingga faktor-faktor yang mempengaruhiinput adalah: keterbatasan anggaran finansial (Hanafi et al, 2017; Hocking et al, 2008; Roy dan Kalindi, 2017; Veillon, 2014) serta keterbatasan sumberdaya manusia (Hamdi, 2015; Hocking et al, 2008; Veillon, 2014). 


\subsubsection{Activities.}

\subsubsection{Studi \& Perencanaan.}

Pelaksanaan pemugaran fasad bangunan merupakan salah satu kegiatan yang sudah direncanakan dalam dokumen "Sawahlunto 2020: Agenda mewujudkan Kota Wisata Tambang yang Berbudaya" yang disusun oleh Pemerintah Daerah bersama LPM ITB (Kuswartojo, 2001). Dalam kajian tersebut dijelaskan bahwa pemugaran fasad dilakukan untuk meningkatkan kualitas visual kawasan.

Terkait program pemugaran fasad, studi/ kajian dibuat secara swakelola oleh Bidang Peninggalan Bersejarah Dinas Pariwisata dan Kebudayaan Sawahlunto. Namun, berdasarkan data yang diperoleh, studi/ kajian yang dibuat lebih fokus pada kajian arsitektur berupa studi fasad. Tidak ditemukan adanya kajian yang secara komprehensif menilai kelayakan, manfaat dan dampak yang mungkin timbul oleh program pemugaran fasad. Selain itu perencanaan atau gambar teknis panduan fasad yang dibuat belum detail dan memenuhi syarat teknis. Dan berdasarkan keterangan masyarakat mereka tidak dilibatkan dalam pembuatan studi dan perencanaan. Sedangkan dalam program konservasi, perencanaan seharusnya dibuat bersama-sama melibatkan semua stakeholder yang berkepentingan terutama warga atau komunitas yang menempati bangunan pada kawasan tersebut(Villiers, 2009). Akibatnya, kajian/ studi dan perencanaan yang dibuat kurang mengakomodasi kebutuhan dan aspirasi masyarakat, dan ditemukan adanya perbedaan (mismatch) antara tujuan program dengan kebutuhan(Radzuan et al, 2014).

Sehingga faktor-faktor yang mempengaruhi aktifitas studi dan perencanaan adalah: keterbatasan sumberdaya(Hanafi et al, 2017; Hocking et al, 2008; Roy dan Kalindi, 2017; Veillon, 2014) dan partisipasi masyarakat dalam perencanaan (Villiers, 2009).

\subsubsection{Sosialisasi.}

Sosialisasi dilakukan agar warga penerima subsidi dapat memahami dengan baik latar belakang, tujuan serta bagaimana program pemugaran akan dilakukan. Berdasarkan wawancara yang dilakukan dengan pengelola kegiatan, ditemukan bahwa pada sosialisasi/ FGD yang dilakukan memang belum optimal dan ditemukan bentuk penolakan oleh masyarakat.Berdasarkan kuesioner terhadap penerima subsidi, ditemukan bahwa sebagian besar masyarakat "menyatakan" mendukung (75\% mendukung, 10\% biasa saja, $15 \%$ tidak mendukung).

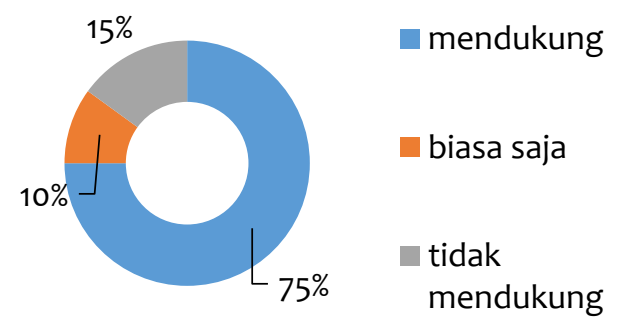

Sumber: kuesioner, 2019

\section{Gambar3. Reaksi Masyarakat pada Sosialisasi}

Namun berdasarkan wawancara dengan warga penerima subsidi, ditemukan adanya unsur "keterpaksaan" dalam partisipasi masyarakat. Hal tersebut disebabkan oleh status legal kepemilikan yang memang secara sah dimiliki oleh perusahaan tambang (PTBA). Terlebih masyarakat merasa kebijakan yang dibuat merugikan dan membatasi mereka, dimana penambahan ruang atau massa bangunan dari bangunan aslinya harus dibongkar, dan berbagai ketentuan lain yang harus diikuti. Akibatnya, cukup banyak warga yang melayangkan protes pada saat sosialisasi, meskipun pada akhirnya mereka menyetujui. 
Selain motif partisipasi karena keterpaksaan (coercive participation) (Rasoolimanesh et al., 2017; Tosun, 1999), ditemukan juga bahwa masyarakat berpartisipasi karena ketertarikan untuk mendapat subsidi (participation for incentives) (Pretty, 1995; Spiridon dan Sandu, 2015). Hal tersebut yang melatar belakangi tingginya tingkat partisipasi masyarakat yang ditemukan oleh Febra (2016), meskipun perlu kajian lebih mendalam untuk menyimpulkannya.

Sehingga faktor-faktor yang mempengaruhi aktifitas sosialisasi adalah: aspek kepemilikan (Hocking et al, 2008), motivasi partisipasi karena insentif (Rasoolimanesh et al, 2017; Spiridon dan Sandu, 2015).

\subsubsection{Pemberian subsidi.}

Setelah program direncanakan dan disosialisasikan, berikutnya Pemerintah melalui instansi terkait mendristribusikan dana kepada masyarakat yang ditunjuk dan bersedia berpartisipasi. Dana Subsidi tersebut diberikan melalui Kantor Lurah Lapang dan langsung diberikan $100 \%$ setelah penerima subsidi menerima gambar dan panduan, serta menandatangani surat pernyataaan bermaterai.

Berdasarkan data kuesioner warga penerima subsidi, hampir sebagian besar masyarakat beranggapan bahwa subsidi sebesar Rp. 10.000.000,- (sepuluh juta rupiah) untuk tiap rumah kurang mencukupi (68\% kurang, $17 \%$ cukup, $15 \%$ sangat kurang.

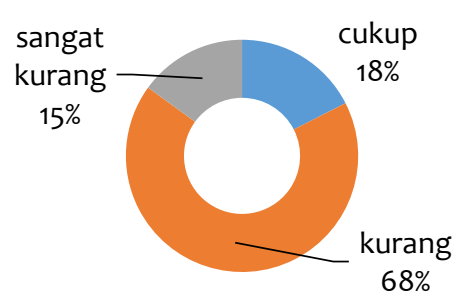

Sumber: kuesioner, 2019

Gambar4. Persepsi Masyarakat terhadap Jumlah Subsidi

Selain itu berdasarkan data yang diperoleh, kesepakatan antara pemerintah dengan warga penerima subsidi hanya dinyatakan dalam bentuk surat pernyataan bermaterai. Menurut peneliti, surat tersebut memiliki kekuatan hukum yang lemah dan berpotensi memiliki pengaruh terhadap komitmen dan kepatuhan penerima subsidi. Seharusnya kesepakatan dibuat dalam bentuk dokumen yang memiliki kekuatan hukum yang jelas (didepan notaris), dan mencantumkan dasar hukum (UU dan peraturan pemerintah lainnya) serta penjelasan mengenai sangsi hukum bila ditemukan pelanggaran.

Sehingga faktor-faktor yang mempengaruhi aktifitas pemberian subsidi adalah: keterbatasan anggaran finansial (Hocking, 2008; Hanafi, 2017; Veillon, 2014; Roy \& Kalindi, 2017) dan legalitas program (Hocking et al, 2008)

\subsubsection{Pelaksanaan \& Pengawasan.}

Untuk mekanisme pelaksanaan, pemugaran fasad diserahkan sepenuhnya kepada masyarakat yang telah ditunjuk dan bersedia melakukan perbaikan fasad bangunan menurut panduan dan pedoman teknis yang diberikan Pemerintah. Berdasarkan wawancara dengan Ibu Rika Cherish (Plt Kepala Kantor Peninggalan Bersejarah dan Permuseuman), mekanisme pelaksanaan secara swakelola masyarakat ini sengaja dipilih karena pertimbangan banyak hal, terutama karena keterbatasan anggaran yang ada dan untuk meningkatkan partisipasi masyarakat dalam pelestarian. Selain itu juga dikarenakan kesulitan teknis dalam membuat anggaran biaya atau estimasi pekerjaan konservasi yang bersifat tambal sulam(Roy dan Kalindi, 2017).

Selain itu pengelola kegiatan yang diwawancarai menyatakan memang banyak kendala pada waktu pelaksanaan, terutama masyarakat yang secara swakelola melakukan pekerjaan memiliki komitmen yang 
rendah untuk melakukan sesuai kesepakatan yang telah dibuat bersama. Selain itu pekerjaan fisik yang sebagian besar dikerjakan oleh tukang yang notabene memiliki pengetahuan teknis yang kurang, serta kendala teknis lainnya seperti kesulitan mencari tukang dan ketersediaan biaya untuk menutup kebutuhan biaya yang tidak terpenuhi oleh subsidi yang diberikan.

Berdasarkan kuesioner pada warga penerima subsidi, sebagian besar mengakui telah mengikuti gambar dan panduan yang diberikan ( $72,5 \%$ mengikuti, 5\% mengikuti sebagian, $22,5 \%$ tidak mengikuti), meskipun berdasarkan data laporan terdapat perbedaan yang cukup signifikan.

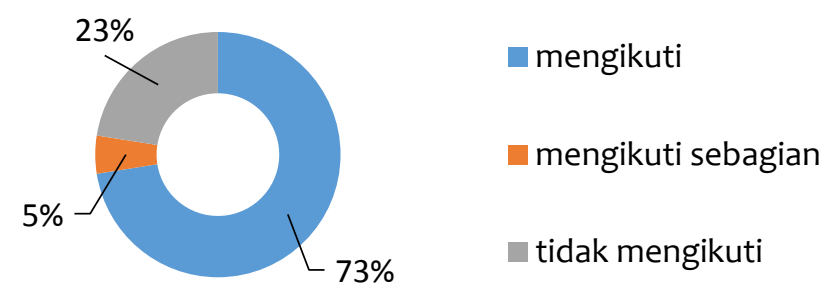

Sumber: kuesioner, 2019

Gambar 5. Persentase Warga Mengikuti Gambar dan Panduan

Namun dalam wawancara dengan warga penerima subsidi mereka mengakui ketidak sukaannya terhadap bentuk fasad yang diberikan, gambar tampak bangunan yang diberikan "tidak jelas", selain itu cukup banyak yang "melanggar" dengan alasan ikut-ikutan. Dan berdasarkan observasi peneliti juga menemukan kecenderungan penerima subsidi untuk mengikuti tren dalam hal gaya bangunan (contoh; minimalis, klasik). Menurut pengakuan masyarakat gambar yang diberikan kurang jelas dan detail, meskipun berdasarkan penilaian peneliti memang ada "kesengajaan" untuk tidak mengikuti gambar panduan yang diberikan. Hal tersebut perlu menjadi perhatian sebagai bentuk fenomena "penyimpangan" dalam partisipasi masyarakat. Dari berbagai literatur partisipasi, manipulasi identik sebagai tindakan yang dilakukan oleh pihak yang berkuasa terhadap masyarakat. Sedangkan dalam pelaksanaan program pemugaran ini, manipulasi juga dapat dilakukan oleh masyarakat yang berpartisipasi. Perlu kajian sosial yang lebih mendalam untuk dapat menyimpulkan dan mendefinisikan "penyimpangan partisipasi tersebut

Dalam kegiatan pengawasan, pengelola kegiatan mengakui bahwa pengawasan yang dilakukan belum optimal. Dan menurut keterangan masyarakat pengawas jarang sekali atau bahkan tidak pernah melakukan kunjungan maupun memberikan pendampingan. Berdasarkan kuesioner terhadap penerima subsidi sebagian besar menyatakan bahwa pengawas hanya seskali melakukan kunjungan (70\% sesekali, 25\% tidak pernah, $5 \%$ sering)

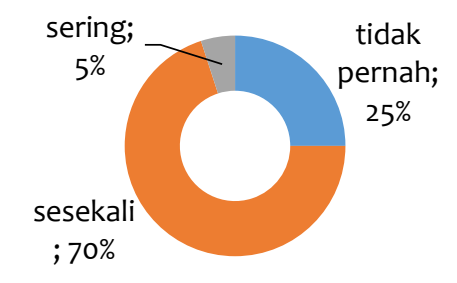

Sumber: kuesioner, 2019

Gambar 6. Persentase Kunjungan Pengawas Menurut Masyarakat

Berdasarkan penjelasan diatas, maka faktor-faktor yang mempengaruhi pelaksanaan dan pengawasan adalah: komitmen (Villiers, 2009), motivasi partisipan(Rasoolimanesh et al, 2017; Spiridon dan Sandu, 2015; Wirastari dan Suprihadjo, 2012), lemahnya pengawasan (Hocking et al, 2008) 


\subsubsection{Output.}

Melalui pelaksanaan yang hampir sepenuhnya diserahkan pada masyarakat tentu akan diperoleh hasil yang bervariatif, terlebih lagi pengawasan dan pendampingan tidak dilakukan dengan baik. Berdasarkan data laporan yang ada diperoleh hasil ketercapaian dan kesesuaian output dengan rencana. Output kegiatan Pemugaran Fasad di Kel. Tanah Lapang dinilai berdasarkan kesesuaian bentuk atap, pintu, jendela dan ventilasi, baik pada bangunan induk maupun bangunan anak. Adapun hasil yang didapat tercapai sesuai rekomendasi sebesar $18,4 \%$, dan tidak sesuai sebesar $81,6 \%$.

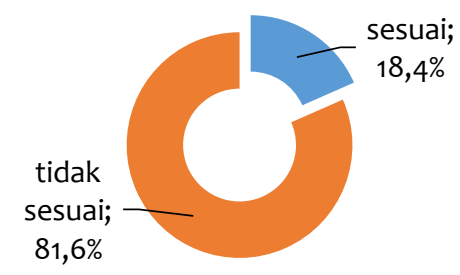

Sumber: laporan kegiatan, 2019

\section{Gambar 7. Persentase Kesesuaian Bentuk Fasad dengan Rencana}

Namun output tidak hanya dinilai berdasarkan kesesuaian bentuk fasad dengan rencana. Output juga dinilai berdasarkan perubahan fisik massa bangunan, dimana berdasarkan laporan kegiatan program ditemukan bahwa keseluruhan (100\%) fasad bangunan yang dipugar dapat dikembalikan sesuai posisi awalnya atau sesuai karakter fisik aslinya. Masyarakat yang berpartisipasi "bersedia" membongkar penambahan ruang pada bagian depan yang menutupi fasad asli bangunan. Sedangkan penambahan ruang (infill) pada bagian samping diperbolehkan sebagai bentuk adaptasi terhadap kebutuhan ruang (adaptive reuse).

Sehingga dapat disimpulkan bahwa output berupa perubahan massa bangunan cukup baik, namun kesesuaian dengan rencana atau otentitas (keaslian) sangat rendah.

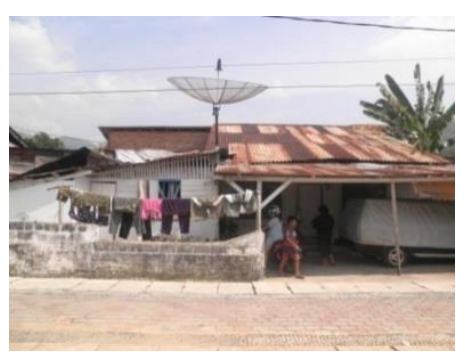

Pra program

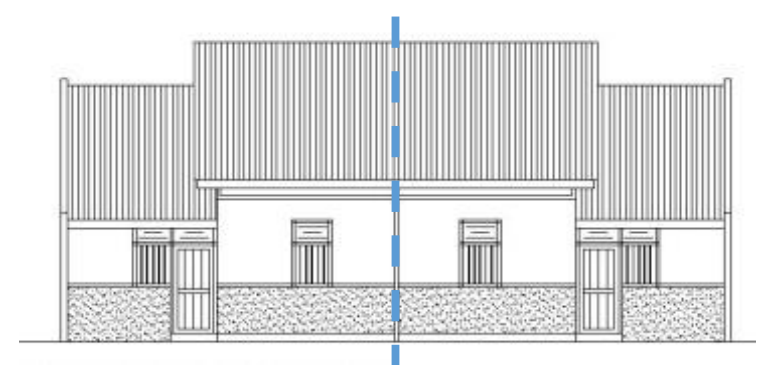

Rencana

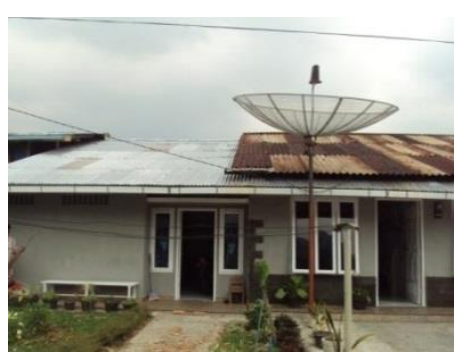

Pasca program

Sumber: laporan kegiatan, 2019

Gambar 8. Kondisi Hunian Sebelum dan Sesudah Program

\subsubsection{Outcome}

\subsubsection{Perubahan karakteristik kawasan}

Kawasan permukiman eks buruh tambang Tanah Lapang secara struktur dan pola ruang memang tidak mengalami perubahan, baik sebelum program pemugaran dilakukan maupun pasca program. Yang menjadi concern pemerintah adalah perkembangan permukiman yang menjadi tidak teratur dan cenderung kumuh, serta mengancam keberadaan nilai sejarah dan karakter fisik asli permukiman tersebut. 
Melalui program pemugaran fasad, perkembangan permukiman tersebut dapat dibatasi dan diupayakan untuk kembali pada karakteristik fisik aslinya meskipun tingkat keaslian otentitas fasad bangunan yang dihasilkan masih sangat rendah.

Namun program tersebut hanya mampu memberikan dampak atau perubahan yang bersifat sementara (jangka pendek), karena selama kebutuhan sesungguhnya masyarakat pada permukiman tersebut belum terakomodasi dengan baik, maka resistensi dan pelanggaran akan selalu ada.

Berdasarkan observasi, terjadi kecenderungan kawasan untuk berubah kembali pada kondisi pra program. Dimana mulai banyak masyarakat melakukan perubahan fasad maupun penambahan ruang atau massa bangunan (infill), membangun pagar dan memasang kanopi (awning). Bentuk-bentuk "pelanggaran" tersebut merupakan bentuk alami respon dan adaptasi terhadap kebutuhan. Masyarakat yang "menambah kembali" ruang beralasan bahwa ruang yang ada sudah tidak mencukupi, terlebih jika ada penambahan anggota keluarga baru. Begitupun halnya dengan membangun pagar yang bertujuan untuk memberi rasa aman pada hunian mereka. Sedangkan pemasangan kanopi (awning) dibutuhkan sebagai peneduh dari sinar matahari dan hujan.

Berbagai "pelanggaran" tersebut memiliki efek berantai, dimana bila salah satu warga melakukannya maka warga lain akan mengikuti. Terlebih lagi belum ada sistem manajemen pengelolaan dan pengendalian yang baik dari instansi yang berwenang(Nurcahyo, 2015). Setelah program berakhir pada tahun 2012 belum ada lagi program lanjutan dari pemerintah, dan terkesan membiarkan "pelanggaran" yang terjadi. Namun berdasarkan wawancara dengan pengelola kegiatan, selama ini mereka telah berupaya mempertahankan dan menindak lanjuti pelanggaran yang ada, bahkan melaporkan pada atasan di instansi berwenang, namun sangat jarang ditindak lanjuti. Bidang Peninggalan Bersejarah dan Permuseuman pada Dinas Pariwisata dan Kebudayaan Sawahlunto selaku instansi yang bertanggung jawab terhadap konservasi cagar budaya, mengeluhkan lemahnya komunikasi dan koordinasi dengan instansi lain dan Pemerintah Daerah. Pelestarian Cagar Budaya belum menjadi perhatian (attention) dan kepedulian (concern) bagi semua pihak, sedangkan dalam upaya konservasi sangat dibutuhkan kerjasama semua pihak yang terkait(Villiers, 2009).

Sehingga faktor-faktor yang mempengaruhioutcome berupa perubahan karakteristik kawasan adalah: lemahnya manajemen pengelolaan \& pengendalian (Hocking et al, 2008; Nurcahyo, 2015), koordinasi (Hamdi, 2015), komunikasi (Villiers, 2009)kebutuhan ruang dan fungsi penunjang(Hanafi et al, 2017), dan rendahnya motivasi masyarakat(Rasoolimanesh et al, 2017; Spiridon dan Sandu, 2015; Wirastari dan Suprihadjo, 2012).

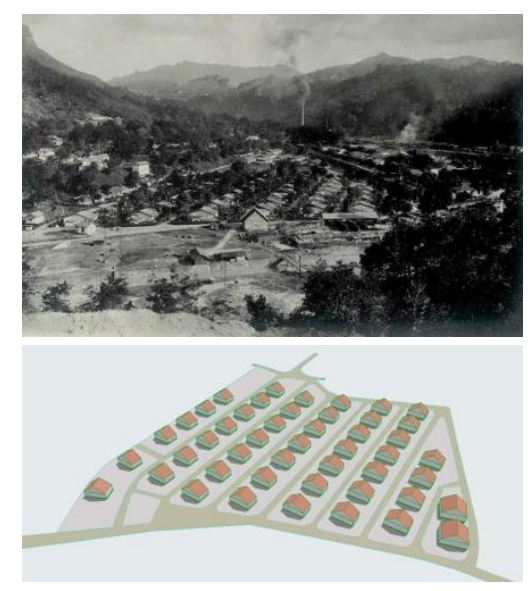

Awal (1910)

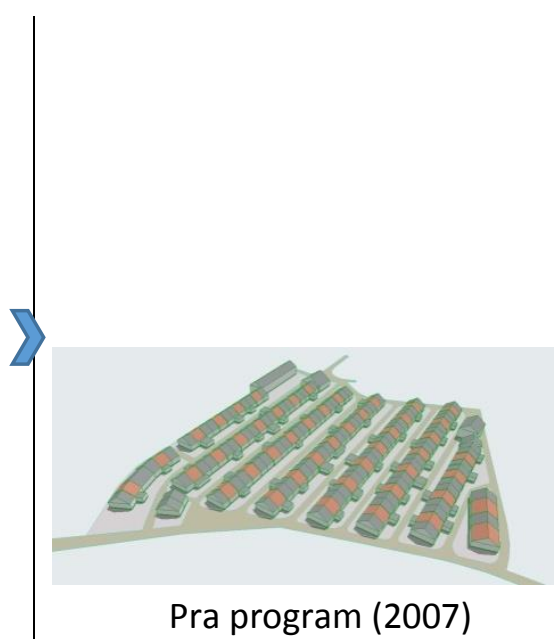

Pra program (2007)

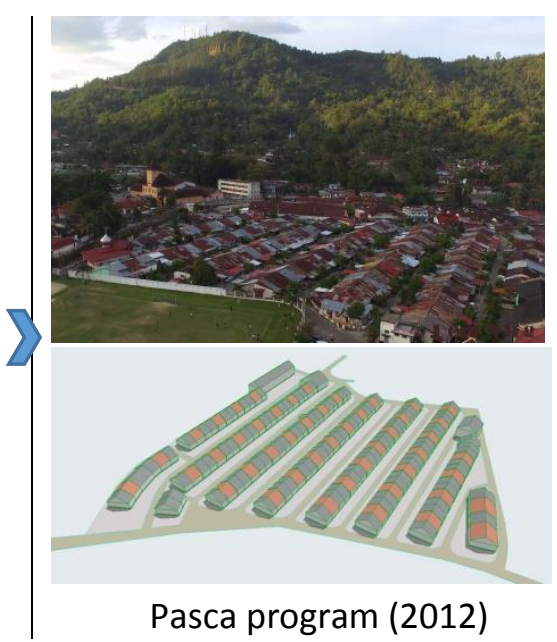

Sumber: Peneliti, 2019

Gambar 9. Ilustrasi Perkembangan Karakteristik Kawasan 


\subsubsection{Perubahan Sikap dan Motivasi Masyarakat Terhadap Upaya Pelestarian}

Melalui program konservasi dengan pemberian subsidi, tentunya diharapkan terjadi perubahan sikap dan motivasi masyarakat terhadap upaya pelestarian. Perubahan tersebut diukur dengan membandingkan sikap masyarakat pada saat sosialisasi (pra program) dengan sikap masyarakat pasca program.

Berdasarkan kuesioner yang dilakukan, ditemukan perpindahan (shifting) 15\% masyarakat yang sebelumnya tidak mendukung program pada saat sosialisasi, menjadi bersikap biasa saja pada pasca program. Dalam artian bahwa masyarakat tersebut sudah mengetahui dan menyadari pentingnya upaya pelestarian, namun belum meyakini bahwa upaya pelestarian tersebut akan mendatangkan manfaat buat mereka.. Sehingga dapat disimpulkan bahwa perubahan sikap dan motivasi masyarakat terhadap upaya pelestarian tidak terlalu signifikan.

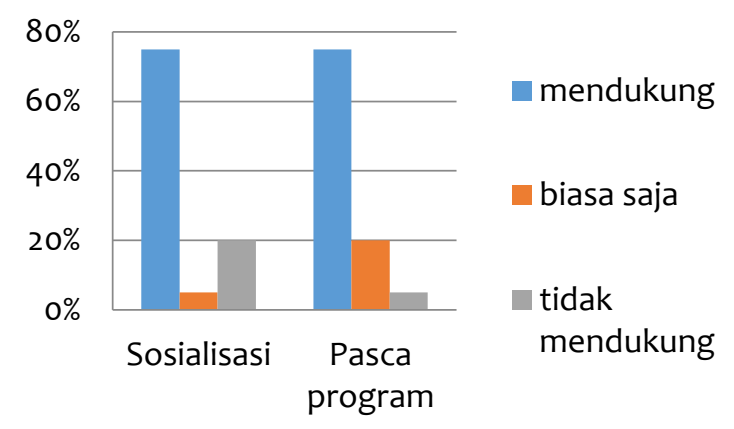

Sumber: kuesioner, 2019

Gambar 10. Diagram Perubahan Sikap dan Motivasi Masyarakat

Selain itu berdasarkan wawancara dengan masyarakat sebagian besar menyatakan kepercayaan dan dukungan terhadap kebijakan pemerintah daerah, namun dalam hal program pemugaran fasad masyarakat belum dapat melihat nilai manfaat dari program tersebut. Bahkan kebijakan tersebut cenderung membatasi dan bertentangan dengan kebutuhan dan keinginan mereka.Suatu proyek konservasi dapat dikatakan sukses bila dapat memberi manfaat nyata bagi masyarakat (Villiers, 2009)

\subsubsection{Pengaruh terhadap aktifitas wisata.}

Perubahan karakteristik kawasan tentunya diharapkan akan berpengaruh terhadap peningkatan aktifitas pariwisata berbasiscagar budaya di Kawasan Kota Lama, dan dapat memberi dampak positif terhadap perekonomian masyarakat. Berdasarkan data dari BPS, kunjungan wisata di Kawasan Kota Lama Kota Sawahlunto dalam kurun 2013-2017 mengalami peningkatan, meskipun pada beberapa tahun terakhir mengalami tren penurunan.

Tabel1. Kunjungan Wisata

\begin{tabular}{|ccccccc|}
\hline No & Obyek Wisata & 2013 & 2014 & 2015 & 2016 & 2017 \\
\hline 1 & Museum Goedang Ransum & 14.000 & 13.725 & 20.943 & 22.287 & 19.619 \\
2 & Museum Kereta Api & 4.842 & 5.657 & 6.557 & 6.423 & 12.220 \\
\hline 3 & Water Boom & 158.745 & 131.949 & 101.063 & 114.003 & 93.446 \\
4 & Taman Satwa Kandih & 262.334 & 190.505 & 160.838 & 110.289 & 89.927 \\
\hline 5 & Lobang Mbak Soero & 10.279 & 10.764 & 12.938 & 10.965 & 10.653 \\
\hline 6 & Desa Wisata Rantih & 5.307 & 5.358 & 6.583 & 5.361 & 5.325 \\
& Jumlah & 455.507 & 357.958 & 308.922 & 269.328 & 231.190 \\
\hline
\end{tabular}

Sumber: Sawahlunto Dalam Angka, 2018 
Menurut pengelola kegiatan, program pemugaran fasad memang tidak ditargetkan untuk meningkatkan aktifitas pariwisata pada kawasan tersebut, karena program tersebut tidak memiliki hubungan langsung dengan aktifitas wisata. Namun melalui peningkatan kualitas visual kawasan diharapkan dapat memberikan "image" lingkungan yangbaik, dan mendukung terciptanya "sense of place" dari kawasan bersejarah tersebut.Selain itu hubungan dan pengaruh antara program pemugaran fasad dengan aktifitas pariwisata dikawasan kota lama perlu untuk dikaji lebih lanjut.

[...] ya kalau untuk menilai pengaruhnya tentu perlu ada kajian, tapi menurut saya tentu saja ada pengaruhnya seperti munculnya wisata minat khusus yang dilakukan kalangan akademis (dosen \& mahasiswa) untuk melakukan kajian tentang penataan kawasan [...] (Axis Citra Pama, Kabid Promosi Wisata Dinas Pariwisata dan Kebudayaan Sawahlunto).

\subsection{Faktor-Faktor yang Mempengaruhi Program}

Berdasarkan paparan dari tahapan program dan faktor-faktor yang mempengaruhinya, kita dapat mengkelompokkan dan menyimpulkan hubungan antara tahapan program dengan faktor-faktor yang mempengaruhinya dalam tabel berikut ini:

Tabel 2. Tahapan Program Pemugaran Fasad melalui Pemberian Subsidi dan Faktor-Faktor yang Mempengaruhinya

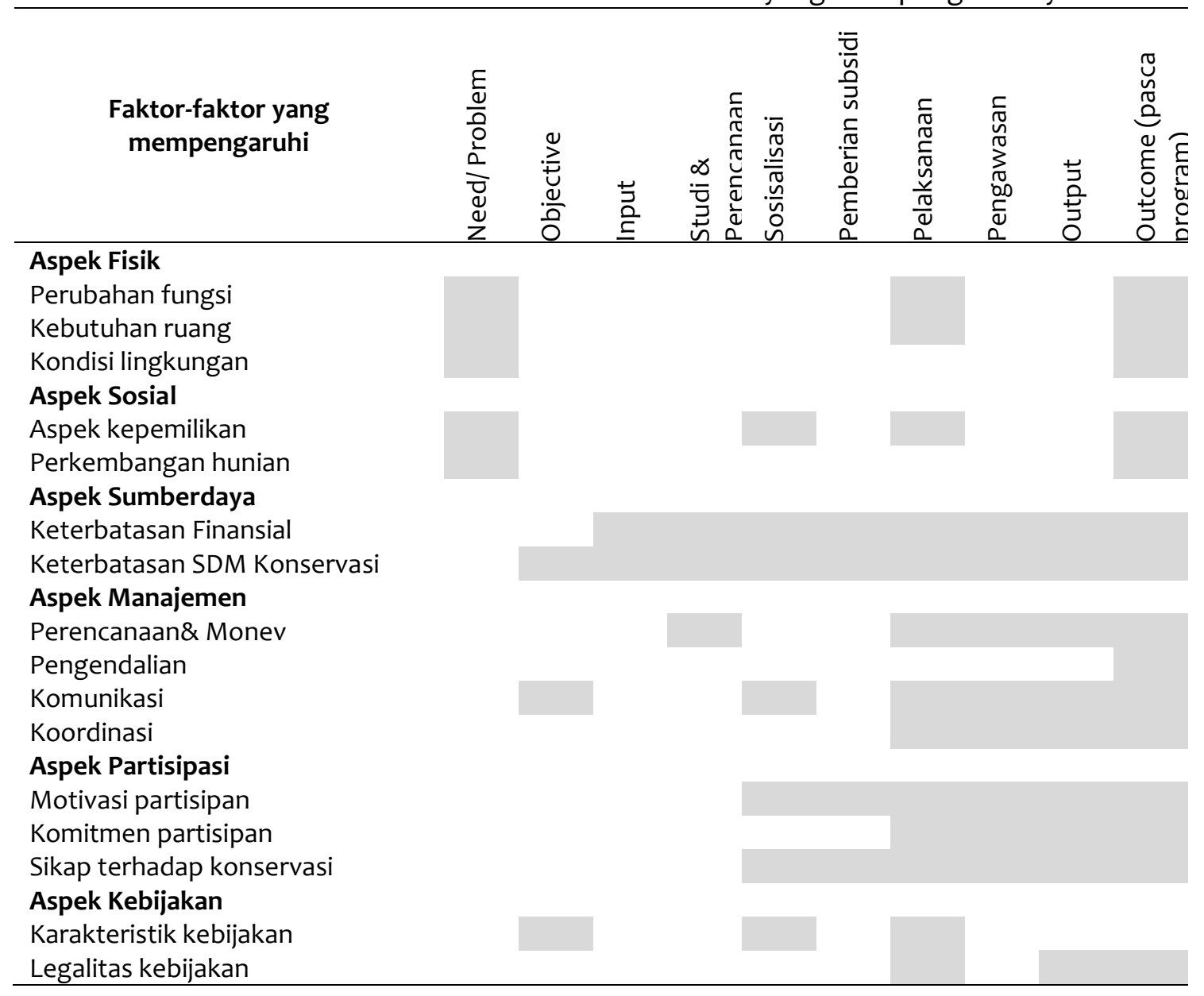

Sumber: Analisa, 2019

Berdasarkan tabel diatas dapat kita lihat bahwa faktor-faktor fisik berupa perubahan fungsi, kebutuhan ruang dan kondisi lingkungan mempengaruhi perubahan bentuk karakteristik fisik bangunan 
pada pra program, dan juga mempengaruhi terjadinya kecenderungan permukiman untuk berubah kembali pada pasca program.Sedangkan faktor-faktorsosialberupa aspek kepemilikan dan perkembangan hunian mempengaruhi kondisi permukiman pra progam, mempengaruhi partisipasi dalam sosialisasi dan pelaksanaan, serta kecenderungan perubahan permukiman pasca program.

Faktor karakteristik kebijakan mempengaruhi perumusan kebijakan, aktifitas sosialisasi dan pelaksanaan pemugaran, sedangkan legalitas kebijakan berpengaruh terhadap pelaksanaan program.

Faktor yang paling besar cakupan pengaruhnya adalah terbatasnya anggaran finansial dan terbatasnya SDM bidang konservasi. Keterbatasan sumberdaya pada input program menciptakan efek berantai yang menyebabkan tidak optimalnya berbagai aktifitas yang dilakukan, dan perubahan yang dihasilkan belum sesuai harapan.

Faktor-faktor manajemen sebagian besar berpengaruh terhadap perencanaan, pelaksanaan dan pengawasan program, serta pemanfaatan dan pengendalian pasca program.Secara umum masyarakat dilibatkan hanya dalam pelaksanaan dan pemanfaatan pasca program, sehingga faktor-faktor partisipasi berupa motivasi, komitmen dan sikap masyarakat terhadap program konservasi, sangat besar pengaruhnya terhadap pelaksanaan dan pemanfaatan pasca program. Terlebih program memang dirancang dengan memberdayakan sumberdaya yang ada pada masyarakat.

\subsection{Relevansi}

Pertanyaan penting untuk menilai relevansi program adalah apakah capaian program yang dihasilkan memiliki kaitan dengan kebutuhan masyarakat dan sudah sesuai dengan agenda dan kebijakan, baik ditingkat daerah, nasional dan global (Bappenas, 2017; Dunn, 2003; OECD, 1991).

Berdasarkan dokumen dan literatur yang diperoleh, Program Pemugaran Fasad memiliki kesesuaian yang tinggi terhadap agenda global, khususnya dalam bidang pelestarian (WHC UNESCO, ICOMOS, ICCROM, dII). Selain itu program pemugaran fasad bisa dikatakan cukup relevan dengan agenda SDG's terutama pada tujuan 11 untuk menciptakan kota dan komunitas yang berkelanjutan melalui hunian yang inklusif, sehat, aman, tangguh dan berkelanjutan.

Sedangkan untuk kebijakan pemerintah pusat \& daerah, sudah tentu Program Pemugaran Fasad memiliki kesesuaian yang tinggi. Karena program pelestarian tersebut dilatar belakangi oleh berbagai aturan terutama UU Cagar Budaya No. 11 Tahun 2010 dan peraturan lainnya yang mengamanatkan kewajiban upaya pelestarian kepada pemerintah.

Indikator relevansi lainnya adalah kesesuaian dengan kebutuhan masyarakat (Bappenas, 2017). Berdasarkan evaluasi yang sudah dilakukan dapat disimpulkan bahwa program pemugaran fasad sangat relevan dengan kebutuhan masyarakat akan biaya perawatan bangunan. Bahkan tidak sedikit masyarakat yang sekaligus memperbaiki bagian bangunan lainnya, seperti plafon, lantai, dinding dan atap.

Namun pada paparan tahapan program pada bagian sebelumnya, ditemukan adanya mismatch antara tujuan program dengan kebutuhan akan ruang dan hunian yang layak. Hal tersebut sejalan dengan pernyataan Radzuan et al (2014) bahwa ketidaksesuaian dapat terjadi bila terdapat perbedaan antara tujuan program dengan kebutuhan sesungguhnya dari masyarakat.

\subsection{Efektifitas}

Tingkat efektifitas program diukur dengan membandingkan tujuan dan output program dengan outcome yang dihasilkan. Pertanyaan - pertanyaan penting terkait efektifitas adalah: apakah program telah mencapai target output dan outcome yang diharapkan, bagaimanakah kualitas pencapaian outcome, bagaimanakah perbandingan outcome yang didapat dengan input dan tujuan program?(Bappenas, 2017)

Berdasarkan evaluasi terhadap outcome pada bagian sebelumnya, ditemukan bahwa perubahan pada karakteristik kawasan memang belum sepenuhnya berhasil mengembalikan autentitas dan karakteristik asli bangunan pada kawasan tersebut, namun pengelola kegiatan menyatakan bahwa setidaknya program berhasil "mengangkat" kembali karakteristik dasar dari kawasan tersebut, dan hal tersebut sudah merupakan capaian yang besar. Dan melalui program pemugaran fasad, telah terjadi peningkatan kualitas 
visual lingkungan pada kawasan tersebut. Namun pasca program, terjadi kecenderungan kawasan untuk berubah kembali kepada kondisi pra program, dengan berbagai bentuk pelanggaran yang dilakukan

Selain itu menurut pengelola kegiatan, program cukup berhasil meningkatkan pengetahuan masyarakat terhadap upaya pelestarian, meskipun belum menyeluruh dan baru hanya sebatas "tahu". Namun setidaknya telah terjadi perubahan sikap masyarakat dalam mendukung upaya pelestarian di Kawasan Kota Lama.Sedangkan untuk hubungan dan pengaruh program terhadap aktifitas wisata memerlukan kajian lanjutan. Namun setidaknya keberadaan objek program (permukiman Tanah Lapang dan area komersil Pasar Remaja yang mendapatkan subsidi) mampu menciptakan wisata minat khusus, seperti penelitian mahasiswa, wisata edukasi, wisata kuliner, dll.

Berdasarkan penjelasan diatas, dapat disimpulkan bahwa pelaksanaan program pemugaran fasad melalui pemberian subsidi pada permukiman eks buruh Tanah Lapang cukup efektif memberikan perubahan dalam jangka pendek, namun belum efektif dalam pelestarian kawasan dalam jangka panjang. Karena perubahan yang dihasilkan hanya bersifat sementara dan terjadi kecenderungan untuk berubah kembali. Dan progam juga belum efektif memberikan dampak peningkatan sikap masyarakat terhadap upaya pelestarian, dan dampak terhadap peningkatan aktifitas wisata.

\subsection{Efisiensi}

Tingkat efisiensi program diukur dengan membandingkan input dengan output yang dihasilkan. Sedangkan indikator yang digunakan adalah rasio antara dana subsidi dengan biaya aktual untuk menghasilkan output. Pada pelaksanaan program pemugaran fasad diperoleh tingkat efisiensi yang tinggi, karena seluruh dana subsidi terserap dengan baik, bahkan tidak sedikit masyarakat yang menggunakan dana pribadi untuk menutupi kebutuhan biaya aktual dari pekerjaan pemugaran tersebut.

[... ] dana subsidi sangat kurang, sedangkan kita memang ingin yang terbaik untuk rumah sendiri, untuk dana pribadi waktu itu saya habis 30 juta [... ] (Bapak BY, warga penerima subsidi)

[... ] dengan besaran subsidi yang hanya sepuluh juta rupiah, kita mampu menstimulus warga agar mau meningkatkan kualitas bangunannya [... ] (Ibu Rika Cherish, ketua tim pengelola kegiatan)

Berdasarkan penjelasan diatas, dapat disimpulkan bahwa pada pelaksanaan program pemugaran fasad yang dilakukan di area Tanah Lapang sangat efisien (efisiensi tinggi).

\subsection{Keberlanjutan}

Keberlanjutan dinilai dengan melihat adanya upaya lanjut setelah program dilaksanakan, baik yang dilakukan oleh masyarakat penerima subsidi, maupun berupa program lanjutan oleh pemerintah. Berdasarkan observasi dan data yang diperoleh, sebagian besar masyarakat hanya berusaha mempertahankan kondisi yang ada, bahkan tidak sedikit yang melanggar dengan melakukan kembali penambahan ruang/ bangunan maupun membangun bangunan baru.

Setelah tahun 2011 program pemugaran fasad bangunan memang tidak dilanjutkan lagi karena keterbatasan anggaran. Namun ada beberapa kegiatan yang bertujuan untuk memotivasi warga untuk tetap mempertahankan melalui kegiatan pemberian reward (kompensasi). Selain itu juga ditemukan kegiatan peningkatan kualitas visual kawasan melalui pengecatan atap dan pemberian tirai di area Pasar Remaja.

[...] Program Pemugaran Fasad melalui pemberian subsidi memang tidak dilanjutkan lagi, karena anggaran yang ada terbatas [... ] ( Bapak Amri Permato, pengelola kegiatan)

[...] saat ini terputus 5 tahun kebelakang, karena kebijakan kurang berpihak kepada pelestarian, namun dengan pemerintahan baru semoga akan ada dukungan yang besar kembali [...] ( Ibu Rika Cheris, pengelola kegiatan) 
[... ] sebagian besar masyarakat masih berupaya mempertahankan bentuk bangunan sesuai rekomendasi [...] ( Bapak Rahmat Gino S.G, pengelola kegiatan)

Berdasarkan penjelasan diatas, dapat disimpulkan bahwa program pemugaran fasad melalui pemberian subsidi memiliki tingkat keberlajutan yang rendah.

Kemudian dari berbagai penjelasan diatas terhadap kriteria relevansi, efektivitas, efisiensi dan keberlanjutan berdasarkan model evaluasi yang digunakan, maka sintesa terhadap hasil evaluasi tersebut dapat digambarkan melalui tabel dibawah ini:

Tabel 3. Sintesa Evaluasi Program Pemugaran Fasad melalui Pemberian Subsidi di Kawasan Kota Lama Sawahlunto

\begin{tabular}{|c|c|c|c|}
\hline No. & Kriteria & Indikator & Penjelasan \& Penilaian \\
\hline 1. & Relevansi & $\begin{array}{l}\text { - } \begin{array}{l}\text { Keterkaitan } \\
\text { dengan program } \\
\text { global agenda } \\
\text { pemerintah }\end{array} \\
\text { - } \begin{array}{l}\text { Keterkaitan antara } \\
\text { tujuan program }\end{array} \\
\text { dengan kebutuhan } \\
\text { masyarakat. }\end{array}$ & $\begin{array}{l}\text { - Program sangat relevan dengan agenda pelestarian } \\
\text { global dan pemerintah } \\
\text { - Adanya ketidaksesuaian antara tujuan program } \\
\text { untuk mengembalikan fasad bangunan dengan } \\
\text { kebutuhan masyarakat terhadap ruang hunian. } \\
\text { Penilaian: Tingkat relevansi sedang }\end{array}$ \\
\hline 2. & Efektivitas & $\begin{array}{l}\text { - Tingkat kesesuaian } \\
\text { output dengan } \\
\text { rencana } \\
\text { - Tingkat ketercapaian } \\
\text { outcome. }\end{array}$ & $\begin{array}{l}\text { - Berdasarkan data yang diolah dari dokumen } \\
\text { kegiatan dan laporan pengawas, ditemukan bahwa } \\
\text { output memiliki kesesuaian terhadap rencana } \\
\text { sebesar } 18,4 \% \\
\text { - Berdasarkan observasi di lapangan disimpulkan } \\
\text { bahwa perubahan terhadap karakteristik kawasan } \\
\text { cukup signifikan. Selain itu tidak terjadi perubahan } \\
\text { yang signifikan terhadap sikap dan pengetahuan } \\
\text { masyarakat terhadap upaya pelestarian kawasan. } \\
\text { Penilaian: Tingkat efektifitas rendah }\end{array}$ \\
\hline 3. & Efisiensi & $\begin{array}{l}\text { Rasio antara subsidi } \\
\text { yang diberikan dengan } \\
\text { biaya sesungguhnya }\end{array}$ & $\begin{array}{l}\text { Dana subsidi yang diberikan terserap dengan baik } \\
\text { keseluruhannya (100\%). Bahkan tidak sedikit dana } \\
\text { pribadi yang dikeluarkan masyarakat untuk menutupi } \\
\text { kekurangan biaya pemugaran fasad. } \\
\text { Penilaian : Tingkat Efeisiensi tinggi }\end{array}$ \\
\hline 4. & Keberlanjutan & $\begin{array}{l}\text { Adanya } \begin{array}{r}\text { program } \\
\text { lanjutan oleh }\end{array} \\
\text { pemerintah, maupun } \\
\text { upaya lanjut oleh } \\
\text { masyarakat. }\end{array}$ & $\begin{array}{l}\text { Program tidak dilanjutkan lagi karena keterbatasan } \\
\text { anggaran pada pemerintah. Dilain pihak masyarakat } \\
\text { hanya berusaha mempertahankan output yang ada, } \\
\text { bahkan tidak sedikit yang melakukan pelanggaran } \\
\text { dengan merubah kembali atau menambah ruang } \\
\text { sehingga menutupi fasad bangunan. } \\
\text { Penilaian: Tingkat keberlanjutan rendah }\end{array}$ \\
\hline
\end{tabular}

Sumber: Analisa, 2019

\section{KESIMPULAN}

Pemugaran fasad melalui pemberian subsidi di permukiman eks buruh Tanah Lapang cukup relevan dengan berbagai agenda dan kebijakan pelestarian cagar budaya. Dan cukup relevan dengan kebutuhan biaya dalam perawatan bangunan cagar budaya.Namun ditemukan adanya ketidak sesuaian antara tujuan program dengan kebutuhan akan ruang dan fungsinya sebagai hunian, karena permukiman tersebut telah berubah fungsi dari barak buruh tambang menjadi hunian keluarga. Perlu kajian lebih lanjut untuk 
mengetahui apakah permukiman tersebut masih relevan dengan fungsinya sebagai hunian dan kebutuhan saat ini, serta bentuk adaptasi yang mungin dapat menjadi solusinya.

Akibat keterbatasan sumberdaya, maka program dirancang dengan pendekatan swakelola dan memberdayakan sumberdaya yang ada pada pemerintah. Perencanaan dan pengawasan dilakukan oleh instansi pemerintah, dan pelaksanaan pemugaran diserahkan pada masyarakat yang menerima subsidi. Kebijakan yang dibuat dengan pendekatan top-downdan non partisipatif cenderung bersifat kontroversi, sehingga pada saat sosialisasi ditemukan adanya unsur penolakan.Partisipasi masyarakat yang cukup tinggi dalam pelaksanaan lebih didasari oleh motivasi atau ketertarikan warga untuk memperoleh subsidi, sertaadanya unsur keterpaksaan akibat aspek kepemilikan.

Melalui pendekatan swakelola dan partisipasi masyarakat melalui pemberian subsidi, diperoleh tingkat efisiensi yang cukup tinggi. Namun dalam pelaksanaannya, terjadi bentuk penyimpangan partisipasi akibat rendahnya komitmen masyarakat dan lemahnya manajemen kegiatan. Akibatnya, output yang dihasilkan belums epenuhnya sesuai dengan rencana, dan pada akhirnya program belum efektif memberi perubahan dan dampak yang diharapkan.

Pasca Program, ditemukan kecenderungan permukiman untuk berubah kembali pada kondisi praprogam. Hal tersebut diakibatkan oleh rendahnya motivasi dan sikap masyarakat terhadap upaya pelestarian,serta lemahnya manajemen pengelolaan dan pengendalian cagar budaya.

\section{PERNYATAAN RESMI}

Penelitian ini dilakukan dalam rangka untuk menyelesaikan studi Magister Perencanaan Wilayah dan Kota, Fakultas Teknik, Universitas Gadjah Mada. Ucapan terima kasih utamanya kepada Allah SWT dan kedua orang tua serta keluarga yang telah memberikan dukungan baik moril dan materil dalam penyelesaian penelitian ini.

\section{REFERENSI}

Bappenas. (2017). Pedoman Evaluasi Pembangunan Nasional. Jakarta: Kementerian Perencanaan Pembangunan Nasional.

Cherish, R. (2014). Perencanaan Konservasi Kawasan Eks Permukiman Buruh Tambang Batubara di Kota Sawahlunto Sumatera Barat. Jurnal Arsitektur Melayu dan Lingkungan, 1(1), 57-74.

Febra, K. (2016). Partisipasi Masyarakat dalam Pelestarian Bangunan Cagar Budaya di Kawasan Kota Lama Sawahlunto. (Master Thesis), Universitas Andalas, Padang.

GAO. (1990). Case Study Evaluation. United States General Accounting Office.

Hamdi, M. (2015). Kebijakan Publik: Proses, Analisis, dan Partisipasi. Bogor: Ghalia Indonesia.

Hanafi, M. H., et al. (2017). Factors Influence on Conservation of Heritage Building in Malaysia. Paper presented at the 2nd International Conference on Social Sciences, Malaysia.

Hocking, M., et al. (2008). Enhancing our Heritage Toolkit: Assessing management effectiveness of natural World Heritage sites: UNESCO World Heritage Center.

Kuswartojo, T. (2001). Sawahlunto 2020 : Agenda Mewujudkan Kota Wisata Tambang yang Berbudaya. Bandung: Pemerintah Kota Sawahlunto.

Nurcahyo, N. T. (2015). Evaluasi Pengelolaan Cagar Budaya Kota Tambang Sawahlunto. (Thesis), Universitas Gadjah Mada, Yogyakarta.

OECD. (1991). DAC Principles for Evaluation of Development Assistance. Retrieved from Paris:

Pollitt, C., \& Bouckaert, G. (2011). Public Management Reform (3rd ed.). Oxford: Oxford University Press.

Pretty, J. (1995). Participatory Learning for Sustainable Agriculture. World Development, 23, 1247-1263. doi:10.1016/0305-750X(95)00046-F

Radzuan, I. S. M., \& Ahmad, Y. (2016). Synthesising An Effective Incentives System In Safeguarding The Heritage Village Of Melaka And George Town. Planning Malaysia: Journal of the Malaysian Institute of Planners(5), 157-168.

Radzuan, I. S. M., et al. (2014). Cultural heritage, incentives system and the sustainable community: Lessons from Ogimachi Village, Japan. GEOGRAFIA Online Malaysian Journal of Society and Space, 10(1), $130-146$.

Radzuan, I. S. M., et al. (2015). A rethink of the incentives programme in the conservation of South Korea's historic villages. Journal of Cultural Heritage Management and Sustainable Development, 5(2), 176-201. 
Rasoolimanesh, S. M., et al. (2017). Community participation in World Heritage Site conservation and tourism development. Tourism Management, 58(c), 142-153.

Roy, D., \& Kalindi, S. N. (2017). Critical challenges in management of heritage conservation projects in India. Journal of Cultural Heritage Management and Sustainable Development, 7(3), 290-307.

Spiridon, P., \& Sandu, I. (2015). Conservation of the Cultural Heritage: From participation to collaboration. ENCATC Journal of Cultural Management \& Policy, 5(1), 43-52.

Tosun, C. (1999). Towards a Typology of Community Participation in the Tourism Development Process. Anatolia, 10, 113-134. doi:10.1080/13032917.1999.9686975

Veillon, R. (2014). State of Conservation of World Heritage Propeties

Villiers, D. J. D. (2009). The Role of Tourism in Heritage and Community Development The Role of Heritage Tourism. Yogyakarta: Gadjah Mada University Press.

Winarno, B. (2014). Kebijakan Publik ( Teori, Proses, dan Studi Kasus ). Yogyakarta: CAPS ( Center of Academic Publishing Service ).

Wirastari, V. A., \& Suprihadjo, R. (2012). Pelestarian Kawasan Cagar Budaya Berbasis Partisipasi Masyarakat (Studi Kasus: Kawasan Cagar Budaya Bubutan, Surabaya). Jurnal Teknik ITS, 1(1), 63-67.

Yin, R. K. (2012). Studi Kasus Desain dan Metode (D. Mudzakir, Trans. 11 ed.). Jakarta: Raja Grafindo Persada. 